\title{
The feeding and rearing systems of Iberian pigs affect the lipid composition and texture profile of dry-cured loin*
}

\author{
E. Soto ${ }^{1}$, L. de la Hoz ${ }^{1}$, J.A. Ordóñez ${ }^{2}$, B. Herranz ${ }^{1}$, E. Hierro ${ }^{1}$, \\ C.J. López-Bote ${ }^{3}$ and M.I. Cambero ${ }^{2,4}$
}

\author{
Complutense University, \\ 'Department of Food Science and Technology, \\ ${ }^{2}$ Institute of Meat Science and Technology, \\ ${ }^{3}$ Department of Animal Production \\ 28040-Madrid, Spain
}

(Received 26 March 2008; revised version 12 November 2008; accepted 23 January 2009)

\begin{abstract}
The effect of growing pigs on free-range (FR) or in confinement with three different diets [acorn (A), acorn and grass (A-G) and formulated diet (FD)] was studied on the dry-cured loin lipid composition and texture profile. Dry-cured loins from FR showed the highest proteolysis degree (estimated as nitrogen from free amino acid and ammonia) and the lowest hardness $(\mathrm{P}<0.05)$, whereas dry-cured loin from FD reached the lowest value of oleic acid (C18:1n-9). Principal component analysis permitted to separate the samples into three different groups: 1. FR products, with high fat content, low SFA and the lowest $n-6 / n-3$ ratio; 2 . FD products, with the lowest fat and the highest SFA and $n-6 / n-3$ ratio and 3. A and A-G products, with high fat, low SFA and $n-6 / n-3$ ratio.
\end{abstract}

KEYWORDS: Iberian pigs, dry-cured loin, fatty acid, $n-6 / n-3$ ratio, texture

\footnotetext{
"Supported by the Science and Technology Ministry Commission (CICYT) and Science and Technology Ministry with the Projects AGL2001-1162 and AGL 2003-05803 and Complutense University and Autonomous Region of Madrid the research group "Food Technology of Animal Origin, 920276" Project CCG07-UCM/AGR-2640 and "TEMINYSA" (S-0505/AGR-0314)

${ }^{4}$ Corresponding author: e-mail: icambero@vet.ucm.es
} 


\section{INTRODUCTION}

An example of traditional productions is the Iberian pig which is an autochthonous pig breed eating acorns and grass in a free-range system located in the Mediterranean forest. Meat products obtained under these ecological conditions are highly appreciated by consumers because of their exceptional sensory quality. It is also possible to feed the Iberian pigs with formulated mixed diets but the sensory attributes of the final products are significantly affected and lead to lower acceptability (Soto et al., 2008). The most valued among them are dry hams and dry-cured loins from animals produced in a free-range system (fed mainly with acorns and grass) due to their sensory characteristic, fatty acid and volatile composition (Soto et al., 2008). These products reach higher prices in markets than those fed mixed diets. The highest quality of these meat products is attributed to the high consumption of acorns, which are rich in oleic acid, at the free-range production system (Cantos et al., 2003). The grass supplies protein which compensates the low protein content in acorns. In addition, grass is rich in $n-3$ fatty acids, which are of interest from the consumer's health point of view (Wood et al., 2003). A previous research on Iberian pigs permitted to conclude that pigs reared on free-range give rise to meat with a higher nutritional and health value which is difficult to imitate by feeding similar diets indoors (Rey et al., 2006). The fatty acid composition was affected by the rearing system with higher accumulation of $n-3$ fatty acids for outdoor rearing pigs, while tocopherol deposition was only affected by the type of feeding.

There is not much information on the effects of the grass intake on pork product characteristics. Some studies in pigs of improved genotypes fed on grass showed no effects on meat quality (Danielsen et al., 2000). On the other hand, the effect of the outdoor rearing has also been studied in light breed pigs but in most of the cases this has resulted in lack of improvements in pig performance (Gentry et al., 2002). Other authors reported increased meat tenderness due to the higher activity of the pigs (Dufey, 1995). Wavreille et al. (2002) carried out a study with different breeds reared indoors on straw or outdoors with access to grass concluding that the rearing system had no effect on fatty acid composition. Daza et al. (2005) reported the effects of feeding diets with different polyunsaturated fatty acids on the accumulation of fatty acids when compared with pigs fed free-range. However, to our knowledge there is no available information on the comparison of Iberian pigs reared free-range with those fed indoors with acorns, acorns and grass or a formulated diet on the lipid and textural characteristics of dry-cured meat products.

The present work was designed to study the effect of feeding system (freerange or confinements with acorns, acorns and grass or a formulated diet) on the 
proteolysis degree, fatty acid and texture profile of Iberian pork dry-cured loin. The ripening of these products takes $80-120$ days being a good experimental model to establish the effect of rearing system (effect of exercise) and pig diet on meat product quality.

\section{MATERIAL AND METHODS}

\section{Experimental design}

Thirty-two castrated male Torbiscal Iberian pigs were selected and from 57 to $100 \mathrm{~kg}$ liveweight they received a commercial diet. In the last fattening phase (from $100.4 \pm 20.8 \mathrm{~kg}$ ) pigs were randomly distributed in four groups. One group (8 pigs) was reared in a free-range (FR) production system for 97 days mainly with pasture and acorns (Quercus rotundifolia). Each pig had an approximately 5 ha of space and the averaged temperature from November to February was $8^{\circ} \mathrm{C}$. The other three groups ( 8 pigs per group) were fed in confinement (individual pens of $8 \mathrm{~m}^{2}$ ) with: A. acorns (Q. rotundifolia), A-G. acorns and grass and FD. a formulated mixed diet (prepared to imitate the free-range diet) for 97 days. The averaged temperature indoors was $14^{\circ} \mathrm{C}$. All pigs were weighed weekly and according to the growth rate reached by the pigs fed in free-range, the groups fed in confinement with acorns or acorns and grass received between 5 and $7 \mathrm{~kg}$ of acorns per day to accomplish a similar growth rate. The amount of grass provided to the pigs fed in confinement with acorns and grass was $2 \mathrm{~kg}$ per day (similar to that estimated in the pigs fed in free-range) and it was all consumed. The group fed in confinement with the formulated diet received $105 \mathrm{~g}$ of concentrate per $\mathrm{kg}$ of metabolic body weight and this value was revised each two weeks. Water was provided ad libitum. Acorns and grass were collected and analysed every week from the forest. The chemical and main fatty acid composition of the formulated diets, acorns and grass are shown in Table 1. The chemical composition of feeds (by triplicate) was determined according to AOAC (1995). The $\alpha$ - and $\gamma$ - tocopherols were determined using the method of Buttriss and Diplock (1984). Fatty acids of diets were extracted and quantified by the one-step procedure of Sukhija and Palmquist (1988) from freeze-dried samples and fatty acids methyl esters were analysed according to López-Bote et al. (2003).

Animals were stunned, slaughtered and exsanguinated at a local slaughterhouse at $154.7 \mathrm{~kg} \pm 3.93$ liveweight. Pork loins were obtained after $24 \mathrm{~h}$ of refrigeration at $4^{\circ} \mathrm{C}$. 
Table 1. Feed ( $\mathrm{g} \mathrm{kg}^{-1}$ product) and fatty acid ( $\mathrm{g} \mathrm{kg}^{-1}$ methyl esters) composition of the diets used to feed Iberian pigs in confinement

\begin{tabular}{lccr}
\hline Item & Acorns & Grass & Formulated diet \\
\hline Composition & & & \\
water & $357.3 \pm 9.6$ & $727.2 \pm 5.2$ & 104.1 \\
crude protein & $31.1 \pm 4.5$ & $40.3 \pm 11.2$ & 126.3 \\
crude fat & $71.1 \pm 18.7$ & $10.2 \pm 7.3$ & 35.9 \\
crude fibre & $6.1 \pm 4.5$ & $42.2 \pm 21.4$ & 39.9 \\
ash & $12.2 \pm 2.7$ & $36.3 \pm 1.5$ & 42.1 \\
N-free extractives & $523.4 \pm 27.7$ & $145.5 \pm 5.4$ & 651.1 \\
$\gamma$-tocopherol & $0.047 \pm 0.017$ & $0.011 \pm 0.007$ & 0.001 \\
$\alpha$-tocopherol & $0.009 \pm 0.007$ & $0.005 \pm 0.001$ & 0.008 \\
& & & \\
Fatty acids & & & 153.9 \\
C16:0 & $164.5 \pm 23.9$ & $216.1 \pm 33.3$ & 0.5 \\
C16:1 $n$-9 & $0.52 \pm 0.4$ & $21.6 \pm 8.9$ & 1.4 \\
C16:1 $n$-7 & $2.1 \pm 1.5$ & $6.9 \pm 4.3$ & 34.3 \\
C18:0 & $33.1 \pm 7.4$ & $21.9 \pm 5.5$ & 311.5 \\
C18: $1 n-9$ & $601.7 \pm 61.3$ & $29.1 \pm 13.6$ & 7.7 \\
C18: $1 n-7$ & $9.7 \pm 3.5$ & $10.8 \pm 8.2$ & 457.4 \\
C18:2 $n-6$ & $180.1 \pm 43.9$ & $140.1 \pm 19.1$ & 24.2 \\
C18:3 $n$-3 & $9.8 \pm 5.6$ & $543.9 \pm 62.1$ & \\
\hline
\end{tabular}

${ }^{1}$ formulated diet, $\mathrm{g} \mathrm{kg}^{-1}$ : barley 532.8, wheat 310.5 , high-oleic sunflower seed 50.1, soyabean meal (44) 81 , calcium carbonate 8.2 , dicalcium phosphate 9.1 , sodium chloride 4 , mineral/vitamin mix 4

\section{Preparation of the experimental dry-cured loins}

For each of the four diets (FR, A, A-G and FD), eight dry-cured loins were prepared using the whole right loin (Longissimus dorsi). All dry-cured loins were manufactured the same day using the same technology, ingredients and formulation (Soto et al., 2008). Raw material: whole pork loin (Longissimus dorsi) of 1.5$2.0 \mathrm{~kg}$ was used, after removing the surface fat and connective tissue. Additives and other ingredients $(\mathrm{g} / \mathrm{kg}$ of raw material): water $25, \mathrm{NaCl} 25$, glucose 5 , curing salts composed of $\mathrm{NaNO}_{3} 2$ and $\mathrm{NaNO}_{2}$, ascorbic acid 1.0, sweet paprika 6, hot paprika 2, powdered garlic 1.5, oregano 0.5 . All the additives and other ingredients were mixed. This mixture was evenly distributed on the loin surface and then loins were left at $4^{\circ} \mathrm{C}$ for $48 \mathrm{~h}$. Afterwards, each loin was stuffed into synthetic case $(90 \mathrm{~mm}$ in diameter). The resulting pieces were ripened together in an Ibercex ripening cabinet, model G-28 (ASL, San Fernando de Henares, Spain). The meat products were kept at $23^{\circ} \mathrm{C}$ and $94 \%$ relative humidity (RH) for $48 \mathrm{~h}$. Then, temperature and $\mathrm{RH}$ were slowly reduced to $7^{\circ} \mathrm{C}$ and $84 \%$, respectively, within $72 \mathrm{~h}$. These ripening conditions were used until the end of the ripening process (a total of 100 days). At that time, water activity $\left(\mathrm{a}_{\mathrm{w}}\right)$ was lower than 0.90 and the 
final product was vacuum-packed and maintained at $4^{\circ} \mathrm{C}$ (less than a week) until sampling. All animals used for this study, as well as the dry-cured loins manufacturing process, fulfilled the requirements of the Spanish regulation (Ministry of Presidency, 2001).

The external case and the outer layer $(1 \mathrm{~cm})$ of the dry-cured loin were discarded before analysis. Samples (without case and outer layer) were packed at vacuum, frozen at $-18^{\circ} \mathrm{C}$ and stored until analysis.

\section{Chemical analysis}

For the estimation of proteolysis degree, the nitrogen content from free amino acids and ammonia was estimated. For that, free amino acids were extracted in an aqueous solution according to Yang and Sepúlveda (1985) and their phenylisothiocyanate (PITC) derivatives analysed by HPLC as described by Bruna et al. (2000). Ammonia levels were determined using the Boehringer kit for enzyme analysis (Boehringer Mannheim, Mannheim, Germany). The nitrogen content (mmol kg-1 of dry matter) was calculated taking in account the molecular weights of free amino acids, ammonia and nitrogen.

Intramuscular lipids from dry-cured loin samples were obtained using the method of Bligh and Dyer described by Hanson and Olley (1963). Fatty acid methyl esters were prepared using the method of Baublits et al. (2006). For this, transmethylation was performed using $1 \mathrm{ml}$ of $1.09 \mathrm{M}$ methanol and $\mathrm{HCl}$ and $1 \mathrm{ml}$ methanol addition to each lipid sample followed by heating at $80^{\circ} \mathrm{C}$ for $30 \mathrm{~min}$ and vortex-mixing every $5 \mathrm{~min}$. Upon cooling, $1 \mathrm{ml}$ of $\mathrm{H}_{2} \mathrm{O}$ and $2 \mathrm{ml}$ of hexane were added to each tube. Tubes were capped and vortex-mixed for about $15 \mathrm{sec}$ and then centrifuged for $3 \mathrm{~min}$ at $900 \mathrm{~g}$. The hexane layer was transferred to gas liquid chromatography (GLC) vials containing anhydrous $\mathrm{Na}_{2} \mathrm{SO}_{4}$. The methyl esters were extracted with $3 \mathrm{ml}$ of petroleum ether. Then, $1 \mu 1$ was analysed using a Perkin Elmer 8420 gas chromatograph (Perkin Elmer, Beaconsfield, UK) equipped with a flame ionization detector and a capillary column HP-Innowax ( $30 \mathrm{~m} \times 0.32 \mathrm{~mm}$ i.d., $0.25 \mu \mathrm{m}$ film thickness). Helium at $2.0 \mathrm{ml} / \mathrm{min}$ was used as carrier gas and the split/splitless injector was used with a split ratio of 10/1. The temperature program was as follows: injector and detector temperature $250^{\circ} \mathrm{C}$, the initial column temperature was $200^{\circ} \mathrm{C}$, which was kept for $2 \mathrm{~min}$, followed by a programmed rise to $245^{\circ} \mathrm{C}$ at $3.5^{\circ} \mathrm{C} \mathrm{min}^{-1}$ and then held for $7 \mathrm{~min}$.

Fatty acid methyl esters were identified by comparison with commercial standards purchased to Sigma Chemical Co. (Saint Louis, MO, USA), excepting C18:2n-7 $\Delta$ cis 9, trans 11 supplied by Nu-Chek-Prep, Inc. (Elysian, MN, USA). These standards were previously run in the same conditions. Samples and commercial standards were injected at least twice and quantified $\left(\mathrm{g} \mathrm{kg}^{-1}\right.$ of total methyl esters). 
The calculated Iodine Index (II) was estimated according to the expression (Cambero et al., 1991):

$$
\mathrm{II}=\mathrm{SII} \times \mathrm{FA}
$$

where: II - total Iodine Index; SII - specific Iodine Index of every fatty acid; FA - concentration of the specific fatty acid obtained by gas chromatography.

\section{Textural analysis}

Texture profile analysis (TPA) was performed using a TA.XT2i SMS Stable Micro Systems Texture Analyser (Stable Microsystems Ltd., Surrey, England) with the Texture Expert programmes. Textural tests were carried out at about $22^{\circ} \mathrm{C}$.

For analysis, a cylindrical probe $\mathrm{P} / 25$ was used. This procedure involved the preparation of four cylinders of $1.5 \mathrm{~cm}$ height and $2 \mathrm{~cm}$ diameter from each sample. A double compression cycle test was performed with up to $50 \%$ compression of the original portion height with an aluminium cylinder probe of $2 \mathrm{~cm}$ diameter. A time of $5 \mathrm{sec}$ was allowed to elapse between the two compression cycles. Forcetime deformation curves were obtained with a $25 \mathrm{~kg}$ load cell applied at a crosshead speed of $2 \mathrm{~mm} / \mathrm{s}$. The following parameters were quantified (Herrero et al., 2007): hardness (N), maximum force required to compress the sample; springiness (m), ability of the sample to recover its original form after deforming force was removed; adhesiveness $(\mathrm{N} \times \mathrm{s})$, area under the abscissa after the first compression; cohesiveness, extent to which the sample could be deformed prior to rupture; gumminess $(\mathrm{N})$, force to disintegrate a semisolid meat sample for swallowing (hardness $\mathrm{x}$ cohesiveness) and chewiness $(\mathrm{J})$, work required to masticate the sample before swallowing.

\section{Statistical analysis}

An individual dry-cured loin was the experimental unit for analysis of all data. A one-way ANOVA, a Duncan test to multiple mean comparisons and a principal component analysis were carried out using a Statgraphics Plus version 5.0. Data were presented as the means of each batch and the standard deviation (SD) of the mean.

\section{RESULTS AND DISCUSSION}

The Figure 1 shows the proteolysis degree of the dry-cured loins estimated as mmol of nitrogen from free amino acid and ammonia $\mathrm{kg}^{-1}$. Also the fat content 


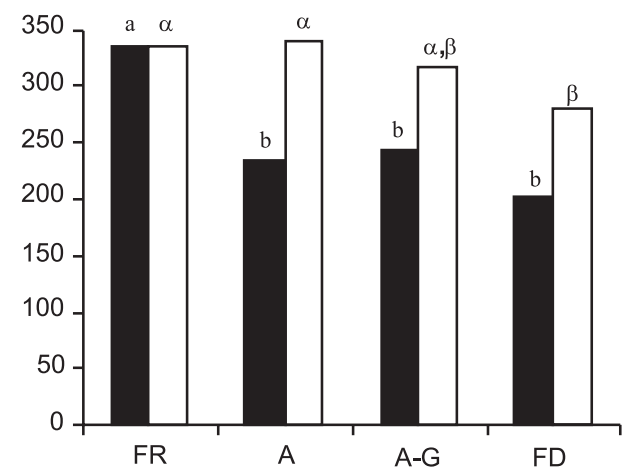

Figure 1. Nitrogen from free amino acids and ammonia $\left(\mathbf{\square}, \mathrm{mmol} \mathrm{kg}{ }^{-1}\right.$ dry matter $)$ and fat content ( $\square, \mathrm{g} \mathrm{kg}^{-1}$ product) of Iberian dry-cured loins*

$\mathrm{a}, \mathrm{b}$ or $\alpha, \beta$ : columns with different letter are significant different $(\mathrm{P}<0.05)$

* Iberian dry-cured loins from animals reared on free-range (FR) or fed in confinement using acorns (A), acorns and grass (A-G) or formulated diet (FD)

( $\mathrm{g} \mathrm{kg}^{-1}$ of product) of the dry cured loins is shown. The product from FR pig showed the highest proteolysis degree $(\mathrm{P}<0.05)$, with values of $334.5 \pm 9.7 \mathrm{mmol} \mathrm{N}$ $\mathrm{kg}^{-1}$ of dry matter, while dry-cured loin from animal fed in confinement showed values between $243.9 \pm 31$ (batch A-G) and $202.1 \pm 57$ (batch FD) $\mathrm{mmol} \mathrm{N} \mathrm{kg}^{-1}$ of dry matter. These results could indicate an effect of animal exercise on the final proteolysis degree of dry-cured products. Similar (Soto et al., 2008) and related (LópezBote et al., 2007) findings have previously been described. Enfält et al. (1993) found higher enzyme activities (citrate synthase and 3-OH-acyl-CoA dehydrogenase) in muscles of trained pigs when compared to untrained ones. The lowest $(\mathrm{P}<0.05)$ fat content was observed in dry-cured loins from pigs fed a formulated diet. These results indicate that the fat content of dry-cured loin is probably more related to diet than to exercise effect. Related findings have been reported by several authors (Rey et al., 2006; Soto et al., 2008). The high fat content of acorns (Table 1) could explain the difference in fat content between products from animal FD and those from pigs fed with diets including acorns (in confinement or free range).

Significant differences $(\mathrm{P}<0.05)$ were found in the fatty acids $\mathrm{C} 14: 0, \mathrm{C} 18: 0$, C18:1n-9, C18:2n-6, C20:0, C20:3n-6 and C20:4n-6 (Table 2) of the different batches. They are reflected in the total saturated, monounsaturated and polyunsaturated fatty acids. Dry-cured loins from formulated diet showed the lowest content $(\mathrm{P}<0.05)$ on C18:1n-9 (about 470 vs $490-500 \mathrm{~g} \mathrm{~kg}^{-1}$ of total methyl esters in the remainder batches). This is a typical difference found in meat, meat products and subcutaneous fat from pigs fed in FR vs those fed on FD, being the oleic acid content of free-range always the highest one (Rey et al., 2006). The products from the formulated diet had high C18:2n-6 content while the C18:3n-3 content did not show significant differ- 
Table 2. Fatty acids of Iberian dry-cured loins ${ }^{1}, \mathrm{~g} \mathrm{~kg}^{-1}$ of total methyl esters

\begin{tabular}{|c|c|c|c|c|}
\hline Fatty acids & Free-range & Acorns & Acorns-Grass & Formulated diet \\
\hline C12:0 & $0.7 \pm 0.1$ & $0.6 \pm 0.1$ & $0.6 \pm 0.1$ & $0.5 \pm 0.3$ \\
\hline $\mathrm{C} 14: 0$ & $10.9 \pm 0.3^{\mathrm{b}}$ & $11.7 \pm 0.8^{\mathrm{b}}$ & $13.1 \pm 1.6^{\mathrm{a}}$ & $10.3 \pm 1.8^{\mathrm{b}}$ \\
\hline C16:0 & $235.1 \pm 7.8$ & $234.4 \pm 19.6$ & $234.1 \pm 5.6$ & $234.2 \pm 9.6$ \\
\hline $\mathrm{C} 16: 1 n-7$ & $27.3 \pm 1.3$ & $25.4 \pm 2.1$ & $25.5 \pm 3.7$ & $22.5 \pm 4.2$ \\
\hline C18:0 & $113.5 \pm 8.8^{\mathrm{b}}$ & $101.6 \pm 17.8^{b}$ & $113.2 \pm 10.1^{\mathrm{b}}$ & $133.3 \pm 14.8^{\mathrm{a}}$ \\
\hline $\mathrm{C} 18: 1 n-9$ & $496.0 \pm 16.0^{\mathrm{a}}$ & $500.0 \pm 10.5^{\mathrm{a}}$ & $492.4 \pm 9.3^{\mathrm{a}}$ & $469.3 \pm 12.6^{\mathrm{b}}$ \\
\hline $\mathrm{C} 18: 1 n-7$ & $30.5 \pm 2.3$ & $26.8 \pm 4.7$ & $26.9 \pm 6.6$ & $25.7 \pm 4.0$ \\
\hline $\mathrm{C} 18: 2 n-6$ & $59.0 \pm 24.1^{\mathrm{b}}$ & $71.4 \pm 18.5^{\mathrm{a}, \mathrm{b}}$ & $67.8 \pm 9.7^{\mathrm{a}, \mathrm{b}}$ & $75.4 \pm 11.5^{\mathrm{a}}$ \\
\hline 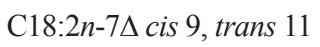 & $0.9 \pm 0.1$ & $0.9 \pm 0.2$ & $0.8 \pm 0.1$ & $0.8 \pm 0.1$ \\
\hline $\mathrm{C} 18: 3 n-3$ & $3.0 \pm 0.4$ & $2.9 \pm 0.5$ & $2.8 \pm 0.5$ & $2.9 \pm 0.4$ \\
\hline $\mathrm{C} 18: 3 n-6$ & $0.5 \pm 0.1$ & $0.4 \pm 0.1$ & $0.4 \pm 0.1$ & $0.5 \pm 0.1$ \\
\hline $\mathrm{C} 20: 0$ & $1.7 \pm 0.1^{b}$ & $1.7 \pm 0.3^{b}$ & $1.7 \pm 0.1^{b}$ & $2.1 \pm 0.2^{\mathrm{a}}$ \\
\hline $\mathrm{C} 20: 1 n-9$ & $10.1 \pm 0.6$ & $10.3 \pm 0.6$ & $10.4 \pm 0.7$ & $10.9 \pm 0.8$ \\
\hline $\mathrm{C} 20: 3 n-6$ & $3.2 \pm 0.1^{\mathrm{b}}$ & $3.9 \pm 0.7^{b}$ & $3.6 \pm 0.5^{b}$ & $4.6 \pm 0.6^{\mathrm{a}}$ \\
\hline $\mathrm{C} 20: 4 n-6$ & $3.5 \pm 0.8^{\mathrm{a}}$ & $3.0 \pm 0.6^{b}$ & $2.8 \pm 0.8^{b}$ & $3.2 \pm 0.4^{\mathrm{b}}$ \\
\hline $\mathrm{C} 20: 5 n-3$ & $0.8 \pm 0.1$ & $0.8 \pm 0.2$ & $0.7 \pm 0.1$ & $0.7 \pm 0.1$ \\
\hline $\mathrm{C} 22: 4 n-6$ & $1.0 \pm 0.2$ & $1.1 \pm 0.2$ & $1.3 \pm 0.4$ & $1.2 \pm 0.2$ \\
\hline $\mathrm{C} 22: 5 n-3$ & $1.1 \pm 0.1$ & $1.3 \pm 0.4$ & $0.9 \pm 0.3$ & $1.0 \pm 0.4$ \\
\hline $\mathrm{C} 22: 6 n-3$ & $0.8 \pm 0.3$ & $1.3 \pm 0.7$ & $0.8 \pm 0.4$ & $0.7 \pm 0.3$ \\
\hline Total SFA & $362.0 \pm 27.8^{b}$ & $350.1 \pm 18.2^{\mathrm{b}}$ & $362.7 \pm 11.8^{b}$ & $380.3 \pm 19.3^{\mathrm{a}}$ \\
\hline Total MUFA & $563.8 \pm 22.4^{\mathrm{a}}$ & $562.5 \pm 11.2^{\mathrm{a}}$ & $555.2 \pm 16.6^{\mathrm{a}}$ & $528.4 \pm 29.7^{b}$ \\
\hline Total PUFA & $73.8 \pm 8.8^{\mathrm{b}}$ & $87.0 \pm 18.5^{\mathrm{a}}$ & $81.8 \pm 10.14^{\mathrm{a}, \mathrm{b}}$ & $91.0 \pm 12.3^{\mathrm{a}}$ \\
\hline$n-6 / n-3$ & $11.8 \pm 0.9^{\mathrm{b}}$ & $12.7 \pm 1.9^{\mathrm{b}}$ & $14.6 \pm 3.2^{\mathrm{a}, \mathrm{b}}$ & $16.0 \pm 3.2^{\mathrm{a}}$ \\
\hline $\mathrm{h} / \mathrm{H}$ & $2.5 \pm 0.1$ & $2.5 \pm 0.2$ & $2.5 \pm 0.1$ & $2.4 \pm 0.2$ \\
\hline II & $66.5 \pm 3.2$ & $68.0 \pm 3.1$ & $65.9 \pm 1.8$ & $65.1 \pm 0.9$ \\
\hline
\end{tabular}

${ }^{1}$ Iberian dry-cured loins from animals reared on free-range or fed in confinement using acorns, acorns and grass or formulated diet

a,b,c - means at the same row with different letter are significant different $(\mathrm{P}<0.05)$

$\mathrm{h} / \mathrm{H}$ : hypocholesterolaemic/hypercholesterolaemic ratio $=[($ sum of C18:1n-9, C18:1n-7, C18:2n-6, $\mathrm{C} 18: 3 n-3, \mathrm{C} 18: 3 n-6, \mathrm{C} 20: 1 n-9, \mathrm{C} 20: 3 n-6, \mathrm{C} 20: 4 n-6, \mathrm{C} 20: 5 n-3, \mathrm{C} 22: 4 n-6, \mathrm{C} 22: 5 n-3$ and $\mathrm{C} 22: 6 n-$ 3)/(sum of C12:0, C14:0 and C16:0); II - Iodine index

ences ( $\mathrm{P}>0.05)$. Rey et al. (2006) found a similar trend on C18:2n-6 content although those authors found the highest value of $\mathrm{C} 18: 3 n-3$ in the subcutaneous fat of FR pigs. Total $n-6$ and $n-3$ fatty acid content and PUFA $n-6 / n-3$ ratio varied considerably depending on the dry-cured loin batches. Significant differences $(\mathrm{P}<0.05)$ for $n-6 / n$ 3 ratio were found between free-range (11.8) and formulated diet (16.0) samples, while A and A-G products showed intermediate values. Neither difference in the iodine index, nor in the hypocholesterolaemic/Hypercholesterolaemic $(\mathrm{h} / \mathrm{H})$ fatty acid ratio (as proposed by Santos-Silva et al., 2002) was found. 
With the variables fat content $\left(\mathrm{g} \mathrm{kg}^{-1}\right.$ of product), total saturated fatty acid ( $\mathrm{g} \mathrm{kg}^{-1}$ of methyl esters) and $n-6 / n-3$ ratio a principal component analysis (PCA) was carried out (Figure 2). Two principal components $(P C 1$ and $P C 2$ ) were extracted from linear combinations of the three variables [PC1: 0.602 (fat) -0.546

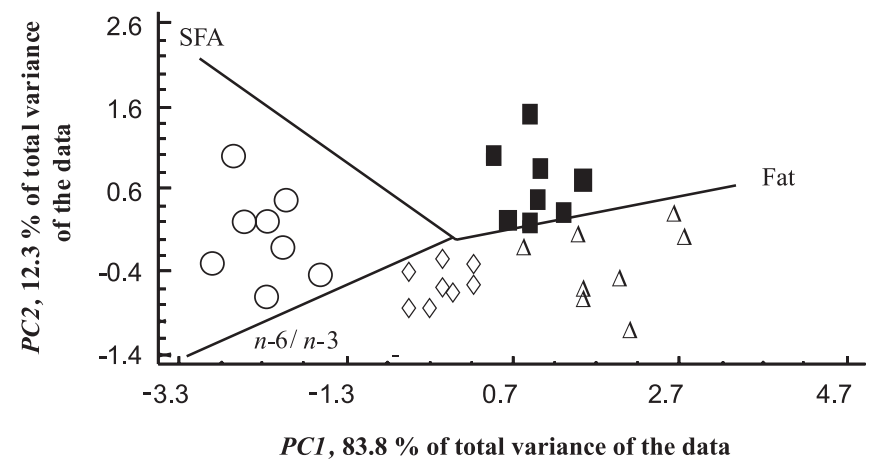

$P C 1: 0.602$ (fat) -0.546 (SFA) $-0.583(n-6 / n-3)$

$P C 2: 0.241$ (fat) +0.820 (SFA) $-0.520(n-6 / n-3)$

Figure 2. Loading plot describing the relationship among Iberian dry-cured loin fat characteristics derived from a principal component analysis (PCA) based on proportion of fat content ( $\mathrm{g} \mathrm{kg}^{-1}$ prod$\mathrm{uct}$ ), total saturated fatty acids (SFA, $\mathrm{g} \mathrm{kg}^{-1}$ total methyl esters) and ratio of PUFA $n-6 / n-3(n-6 / n-3)$ from animals reared at free-range $(\boldsymbol{\square})$ or fed in confinement using acorns $(\Delta)$, acorns and grass $(\diamond)$ or formulated diet (O)

(SFA) - $0.583(n-6 / n-3)$ and PC2: 0.241 (fat) +0.820 (SFA) - $0.520(n-6 / n-3)]$. The two PC together accounted for $96 \%$ of the variability in the dry-cured loin data $(83.8 \%$ by $P C 1$ and $12.3 \%$ by $P C 2)$. This analysis allows to separate samples (Figure 2) in three different groups: 1. dry-cured loins from free-range, with high fat content, low SFA and the lowest $n-6 / n-3$ ratio; 2 . products from formulated diet, with the lowest fat content and the highest SFA and $n-6 / n-3$ ratio and 3 . products from acorns and acorns-grass, with high fat, low SFA and $n-6 / n-3$ ratio. Textural properties of dry-cured loins are shown in Table 3. Significant differences $(\mathrm{P}<0.05)$ were found for hardness, adhesiveness, cohesiveness and chewiness. Results for hardness showed significant differences $(\mathrm{P}<0.05)$ between free-range and the other samples, ranging from 130 (batch FR) to about $160 \mathrm{~N}$ (batches A, A-G, FD). Those variations may be related to the previous results showed in Figure 1 (fat and nitrogen from proteolysis), Table 2 (fatty acid composition) and the finding of other authors (Enfält et al., 1993; Gentry et al., 2002; Soto et al., 2008) related with the effect of rearing system. The clearest effect is probably arisen from the proteolysis degree (nitrogen from free amino acids and ammonia). Thus FR dry-cured loins showed the highest proteolysis which was correlated with the 
Table 3. Textural profile analysis of Iberian dry-cured loins ${ }^{1}$

\begin{tabular}{lcccc}
\hline Item & Free-range & Acorns & Acorns-grass & Formulated diet \\
\hline Hardness $(\mathrm{N})$ & $129.87 \pm 28.59^{\mathrm{b}}$ & $169.24 \pm 21.13^{\mathrm{a}}$ & $158.43 \pm 10.40^{\mathrm{a}}$ & $147.07 \pm 15.36^{\mathrm{a}}$ \\
Adhesiveness $(\mathrm{N} \mathrm{s})$ & $-0.64 \pm 0.13^{\mathrm{a}, \mathrm{b}}$ & $-0.58 \pm 0.18^{\mathrm{a}, \mathrm{b}}$ & $-0.68 \pm 0.12^{\mathrm{a}}$ & $-0.52 \pm 0.19^{\mathrm{b}}$ \\
Springiness $\left(\mathrm{m1} 0^{-3}\right)$ & $0.29 \pm 0.03$ & $0.31 \pm 0.15$ & $0.21 \pm 0.07$ & $0.24 \pm 0.12$ \\
Cohesiveness & $0.49 \pm 0.02^{\mathrm{a}}$ & $0.38 \pm 0.03^{\mathrm{c}}$ & $0.41 \pm 0.11^{\mathrm{b}, \mathrm{c}}$ & $0.45 \pm 0.04^{\mathrm{a}, \mathrm{b}}$ \\
Gumminess $(\mathrm{N})$ & $63.42 \pm 11.24$ & $64.61 \pm 12.98$ & $64.44 \pm 19.88$ & $66.95 \pm 15.47$ \\
Chewiness $(\mathrm{J})$ & $0.018 \pm 0.004^{\mathrm{a}, \mathrm{b}}$ & $0.020 \pm 0.005^{\mathrm{a}}$ & $0.014 \pm 0.007^{\mathrm{b}}$ & $0.016 \pm 0.004^{\mathrm{a}, \mathrm{b}}$ \\
\hline
\end{tabular}

${ }^{1}$ Iberian dry-cured loins from animals reared on free-range or fed in confinement using acorns, acorns and grass or formulated diet; ${ }^{a, b, c}$ - means at the same row with different letter are significant different $(\mathrm{P}<0.05)$

lowest hardness. On the other hand, but with less effect, it is possible that low fat content, high SFA and low unsaturated fatty acid content could, all together, induce to harder samples. This combination is observed in samples from batch FD which showed also the lowest nitrogen from free amino acid and ammonia. In a similar way, Enfält et al. (1993) and Gentry et al. (2002) found shear force values $(\mathrm{P}<0.05)$ greater in meat from indoor-finished pigs than from outdoor-finished animals. Gentry et al. (2002) stated that outdoor-reared pigs gave more $(\mathrm{P}<0.05)$ tender pork, although both samples means were acceptable in pork tenderness and no differences were detected in sensory panel tenderness scores.

\section{CONCLUSIONS}

From the results obtained it could be concluded that free-range raising of pigs plays an important role in the lipid composition and hardness of pork dry-cured loin. On the other hand, raising pigs indoors leads to harder products probably due to a lower proteolysis degree. Animals fed in confinement with either acorns or acorns-grass produced dry-cured loins enriched in fat and MUFA when compared to formulated diet. Meat products from pigs reared free-range and from animals fed acorns in confinement showed the lowest PUFA $n-6 / n-3$ ratio. The indoor rearing is a possibility for Iberian pig but it is necessary to take in account that some differences could be detected in the meat dry-cured final product in relation with those from free-range animals. 


\section{REFERENCES}

AOAC, 1995. Association of Official Analytical Chemists, Official Methods of Analysis. 16th Edition. Washington, DC

Baublits R.T., Pohlman F.W., Brown A.H., Rule D.C., Johnson Z.B., Onks D.O., Murrieta C.M., Sandelin B.A., Richards C.J., Loveday H.D., Pugh R.B., 2006. Comparison of fatty acid and sensory profiles of beef from forage-fed cattle with retail united states department of agriculture choice and select beef. J. Muscle Foods 17, 311-329

Bruna J. M., Fernández M., Hierro E.M., Ordóñez J.A., Hoz L., 2000. Improvement of the sensory properties of dry fermented sausages by the superficial inoculation and/or the addition of intracellular extracts of Mucor racemosus. J. Food Sci. 65, 731-738

Buttriss J.L., Diplock A.T., 1984. High performance liquid chromatography methods for vitamin E in tissues. Method Enzymol. 105, 131-138

Cambero M.I., Hoz L., Sanz B., Ordoñez J.A., 1991. Lipids and fatty acids composition of rabbit meat. Part I.- Apolar fraction. Meat Sci. 29, 153-166

Cantos E., Espin J.C., López-Bote C.J., de la Hoz L., Ordóñez J.A., Tomas-Barberan F.A., 2003. Phenolic compounds and fatty acids from acorns (Quercus spp.), the main dietary constituent of freeranged Iberian pigs. J. Agr. Food Chem. 51, 6248-6255

Danielsen V., Hansen L.L., Moller F., Bejerholm C., Nielsen S., Hermansen J.E., 2000. Ecological animal husbandry in the Nordic countries. In: Proceeding from NJF-Seminar No. 303, Horsens (Denmark), pp. 79-86

Daza A., Mateos A., Rey A.M., Lopez-Bote C.J., 2005. Feeding level in the period previous to the late fattening phase influences fat composition at slaughter in free-ranged Iberian pigs. Arch. Anim. Nutr. 59, 227-236.

Dufey P.A., 1995. Meat and fat quality in finishing pigs at pasture. Agrarforschung 2, 453-456

Enfält A.C., Lundstrom K., Hansson I., Karlsson A., Essen-Gustavsson B., Hakansson J., 1993. Moderate indoor exercise: effect on production and carcass traits, muscle enzyme activities and meat quality in pigs. Anim. Prod. 57, 127-135

Gentry J.G., McGlone J.J., Miller M.F., Blanton J.R., 2002. Diverse birth and rearing environment effects on pig growth and meat quality. J. Anim. Sci. 80, 1707-1715

Hanson S.W.F., Olley J., 1963. Application of the Bligh and Dyer method of lipid extraction to tissue homogenates. Biochem. J. 89, 101P-102P

Herrero A.M., Ordóñez J.A., Romero de Avila M.D., Herranz B., Hoz L., Cambero M.I., 2007. Breaking strength of dry fermented sausages and their correlation with Texture Profile Analysis (TPA) and physico-chemical characteristics. Meat Sci. 77, 331-338

López-Bote C.J., Isabel B., Ruiz J., Daza A., 2003. Effect of vitamin E supplementation and partial substitution of poly- with monounsaturated fatty acids in pig diets on muscle, and microsome extract $\alpha$-tocopherol concentration and lipid oxidation. Arch. Anim. Nutr. 57, 11-25

López-Bote C.J., Toldra F., Daza A., Ferrer J.M., Menoyo D., Silio L., Rodriguez M.C., 2007. Effect of exercise on skeletal muscle proteolytic enzyme activity and meat quality characteristics in Iberian pigs. Meat Sci. 79, 71-76

Ministry of Presidency, 2001. Royal Order 1083/2001 of 5th October for quality regulation of Iberian dry-cured ham, Iberian dry-cured shoulder and Iberian dry-cured loin manufactured in Spain (in Spanish). Spanish Official Gazette, 247

Rey A.I., Daza A., López-Carrasco C., López-Bote C.J., 2006. Feeding Iberian pigs with acorns and grass in either free range or confinement affects the carcass characteristics and fatty acids and tocopherols accumulation in Longissimus dorsi muscle and backfat. Meat Sci. 73, 66-74 
Santos-Silva J., Bessa R.J.B., Santos-Silva F., 2002. Effect of genotype, feeding system and slaughter weight on the quality of light lambs. II. Fatty acid composition of meat. Livest. Prod. Sci. 77, 187197

Soto E., Hoz L., Ordóñez J.A., Hierro E., Herranz B., López-Bote C., Cambero M.I., 2008. Impact of feeding and rearing systems of Iberian pigs on volatile profile and sensory characteristics of drycured loin. Meat Sci. 79, 666-676

Sukhija P.S., Palmquist P.L., 1988. Rapid method for determination of total fatty acid content and composition of feedstuffs and faeces. J. Agr. Food Chem. 36, 1202-1206

Wavreille J., Faes T., Sindic M., Clautriaux J.J., Lognay G., Bartiaux-Thill N., 2002. Comparison of growth the performance and meat quality of pigs $1 / 4$ Landrace Francais- $1 / 4$ Duroc- $1 / 2$ Pietrain and $1 / 4$ Landrace Francais- $1 / 4$ Large-White- $1 / 2$ Pietrain reared indoors on straw or outdoor with access to grass. In: 34 Journées de la Recherche Porcine sous l'Egide de 1' Associations Francaise de Zootechnie, Paris (France), pp. 23-29

Wood J.D., Richardson R.I., Nute G.R., Fisher A.V., Campo M.M., Kasapidou E., 2003. Effects of fatty acids on meat quality: A review. Meat Sci. 66, 21-32

Yang C., Sepúlveda F., 1985. Separation of phenylthiocarbamyl amino acids by high performance liquid chromatography on Spherisorb octadecysilane columns. J. Chromatogr. 346, 413-416 